\title{
MEMBANGUN KEPRIBADIAN MUSLIM MELALUI TAKWA DAN JIHAD
}

\author{
Moh. Arif \\ STAIN Tulung Agung \\ moharif@g.mail.com
}

\begin{abstract}
Abstrak
Artikel ini membahas tentang konsep Taqwa dan Jihad dalam al-Qur'an. Taqwa sekalipun pendek pelafalannya namun merupakan himpunan dari semua kebaikan dan kumpulan dari hak dan kewajiban; sedangkan jihad "merupakan "ruhbaniyah", karena dengan jihad kaum muslimin telah meninggalkan kelezatan duniawiyah. Kepribadian seorang muslim tidak terlepas dari cita-cita Islam yang meliputi penyerahan diri, kepasrahan, ketundukan, dan kepatuhan terhadapsang pencipta. Allah memerintahkan orang muslim untuk bertaqwa sebelum memerintahkan hal-hal lain, agar taqwa itu menjadi pendorong bagi mereka untuk melaksanakan perintahperintah-Nya. Mentaati segala apa yang telah dianjurkan oleh Allah SWT dan Rasul-Nya dan an menjauhi sebisa mungkin segala apa yang telah dilarang-Nya merupakan salah satu ciri dari taqwa. Adapun keterkaitan taqwa dan jihad ialah seorang Muslim harus melaksanakan semua yang telah dianjurkan oleh Allah swt dan Rasul-Nya tanpa memikirkan keuntungan dan kerugian dalam menjalankan syariat-Nya. Kesemuanya itu dapat terwujud melalui pengamalan perintah Allah sebagai suatu bentuk jihad fisabilillah.
\end{abstract}

\section{Abstract}

BUILD OF PERSONALITY MUSLIM WITH TAQWA AND JIHAD. This article discusses the concept of Taqwa and Jihad in the Qur'an. The term taqwa, though short to pronunciate, is a set of all goodness and a collection of rights and obligations; whereas the term jihad "is the "ruhbaniyah (congregation)" because in performing jihad the Muslims have to put aside the worldly delights. The personality of a Muslim can not be separated from the ideals of Islam that includes surrender, resignation, submission, and obedience to the creator. Allah commands Muslims to fear Him before ordering other 
things in order that the piety becomes incentive for them to carry out His commands. Complying with all that has been recommended by Allah and His Messenger and being away as much as possible from all that has been banned is one of the characteristics of taqwa. As for the linkage between piety and jihad, a Muslim must perform all that has been recommended by Allah and His Messenger without thinking about the advantages and disadvantages in running his law. All of them can be realized through the implementation of God commandment as a form of jihad fisabilillah.

Kata kunci : Taqwa, Jihad, Kepribadian

\section{A. Pendahuluan}

Ajakan al-Qur'an pada taqwa menggunakan berbagai macam cara, dari perintah secara langsung, menjelaskan beberapa pengaruhnya, pujian terhadap orang yang bertaqwa, memaparkan kebaikan dan keutamaan mereka, peringatan terhadap orang yang meninggalkan dan berpaling kepada-Nya, sehingga jelas perbedaan orang yang bertaqwa dengan orang-orang yang yang berpaling yang berbuat kekejian, atau orang-orang yang baik dan bertaqwa dengan orang-orang yang berbuat dosa dan pelanggaran.

Dalam istilah taqwa biasanya diartikan sederhana sebagai "takut kepada Tuhan" yang dilaksanakan dengan "menjauhi segala larangan-Nya, menjalankan semua perintah-Nya." Barangkali inilah pengertian umumnya dikalangan umat Islam, tentang arti taqwa. Karena itulah maka penerjemah Inggris J.M. Rodwell, mengalihbahasakan muttaqin menjadi God-Fearing, atau orang yang takut (kepada Tuhan).

Berdasarkan penelahannya mengenai nilai-nilai budaya Arab pra-Islam, Prof. T. Izutsu, yang karyanya mengandung unsur-unsur metodologi penafsiran al-Qur'an dan banyak dipakai referensi para pengarang Muslim modern itu, berspekulasi bahwa konsep taqwa ini, yang berasal dari budaya tradisional, diangkat oleh al-Qur'an sebagai gebrakan terhadap sifat-sifat kesombongan, kecongkakan dan keangkuhan bangsa arab agar mereka menurunkan rasa takaburnya yang berlebih-lebihan. Dalam pengertian taqwa yang ia simpulkan, "terkandung suasana takut," yang menurut analisisnya terhadap keseluruhan sistem nilai etika dalam al-Qur'an, merupakan basis agama yang paling mendasar." Takut ini, katanya 
hampir sinonim dengan percaya dan pengabdian. ${ }^{1}$ Dan kelapangan bisa juga penyebab kebersamaan Allah dengan hamba-Nya. Taqwa dapat pula menumbuhkan etos pemilah dalam diri manusia yang mampu membedakan antara kebenaran dan kebatilan dan bisa pula menjadi penentu diterimanya amal perbuatan manusia di sisi Allah swt.

Taqwa yang telah dipaparkan memiliki format dan tampilan, selain juga substansi dan hakikat. Format dari taqwa tersebut bisa berbentuk penjagaan terhadap praktik ibadah, penjagaan cara pelaksanaannya, perhatian pada perbuatan ang-gota tubuh, ketaatan fisik, dan bukan pada perbuatan hati atau ketaatan hati. Format taqwa ini juga termanifestasi dalam upaya menghindari maksiat qalbu. Format ini juga memfokuskan perhatiannya pada perilaku yang tampak di mata kebanyakan orang, tanpa memperhatikan perilaku batin yang kurang terlihat oleh mereka.

Sedangkan substansi dan hakikat taqwa lebih tampak di hati yang notabene merupakan focus perhatian Allah swt. Dan pangkal keselamatan di akhirat. Taqwa secara formalitas memang banyak memperhatikan pelaksanaan ibadah yang kasat mata dan gerakan-gerakan badan yang terlihat, seperti berdiri dalam shalat, ruku serta sujud; tanpa memperhatikan kekhusyuan inilah yang akan dibalas Allah swt. dengan keberuntungan. ${ }^{2}$

Taqwa dalam pengertian yang mendasar adalah sejajar dengan pengertian rabbaniyyah (semangat ketuhanan) dalam firman yang lain, yang menuturkan salah satu tujuan pokok diutusnya nabi atau rasul kepada umat manusia. Kata-kata rabbaniyyah meliputi "sikap-sikap pribadi yang secara bersungguhsungguh berusaha memahami Tuhan dan mentaati-Nya”, sehingga dengan sendirinya ia mencakup pula kesadaran akhlaki manusia dalam kiprah hidupnya di dunia ini. ${ }^{3}$ Untuk itu perlu dirumuskan sebuah rumusan sebagai berikut: Bagaimana makna taqwa

${ }^{1}$ Dawam Raharjo, Ensiklopedi al-Qur'an, (Jakarta: Paramadina, 1996), h. 155.

${ }^{2}$ Yusuf al-Qarḍawi, Bagaimana Berinteraksi dengan al-Qur'an, terj. Kathur Suhardi, (Jakarta: Pustaka al-Kautsar, 2003), h. 16-19.

${ }^{3}$ Nurcholis Madjid, Islam Doktrin dan Peradaban, (Jakarta: Paramadina, 2000), h. $45-46$. 
sebagai indikator kepribadian muslim? Bagaimana keterkaitan makna taqwa dengan wasilah dan jihad untuk mencapai pribadi yang benar?

\section{B. Pengertian Makna Taqwa}

Taqwa menurut bahasa adalah takut, sedangkan menurut istilah menjalani apa yang telah disyariatkan-Nya serta menjauhi segala apa yang dilarang-Nya. Allah memerintahkan orang muslim untuk bertaqwa sebelum memerintahkan hal-hal lain, agar taqwa itu menjadi pendorong bagi mereka untuk melaksanakan perintahperintah-Nya, ${ }^{4}$ sebagaimana firman-Nya dalam QS. al-Māidah (5) : 35:

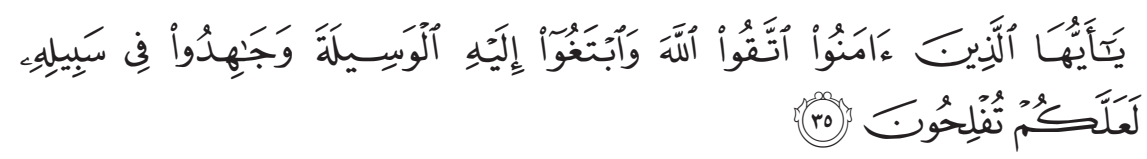

"Hai orang-orang yang beriman bertaqwalah Kepada Allah dan carilah jalan yang mendekatkan diri kepada-Nya, dan berjihadlah pada jalan-Nya, supaya kamu mendapat keberuntungan. ${ }^{5}$

Dari itu di sinilah Allah menyuruh kaum mu'minin supaya bertaqwa kepada-Nya dan mencari jalan yang dapat mendekatkan diri kepada-Nya dengan melakukan amal soleh dan jangan sampai terpedaya dengan agama mereka, seperti yang dialami orang-orang ahli Kitab.

Hal itu kemudian ditegaskan lagi oleh Allah, dengan menerangkan, bahwa kemenangan dan kebahagiaan hanyalah bias diperoleh dua perkara tersebut. Oleh karenanya, barangsiapa tidak melakukannya, maka dia akan menemui berbagai macam penderitaan, kelak dihari kiamat yang sulit dilukiskan.

Ayat ini menyentuh jiwa manusia dengan mengajaknya mendekatkan diri kepada Allah. Ajakan tersebut ditujukan kepada orang-orang yang walau mempunyai secercah iman, sebagaimana dipahami dari penggilan Wahai orang-orang yang beriman, walau hanya sekelumit iman bertakwalah kepada Allah dan hindari siksaan-

${ }^{4}$ Yusuf al-Qaradiawi, Bagaimana..., h. 85-90.

${ }^{5}$ Departemen Agama, Al-Qur'an dan Terjemahannya, (Jakarta: Tim Pentashih al-Qur'an, 1997), h. 165. 
Nya baik duniawi maupun ukhrawi dan bersungguh-sungguhlah mencari jalan dan cara yang dibenarkan-Nya yang mendekatkan diri kamu kepada-ridha-Nya, dan berjihadlah pada jalan-Nya, yakni kerahkanlah semua kemampuan kamu lahir dan batin untuk menegakkan nilai-nilai ajaran-Nya, termasuk berjihad melawan hawa nafsu kamu supaya kamu mendapatkan keberuntungan, yakni memperoleh apa yang kamu harapkan baik keberuntungan duniawi atau ukhrawi.

Sesungguhnya seluruh kebaikan merupakan buah dari ketaatan kepada Allah. Taat kepada Allah swt akan mengumpulkan kebaikan. Allah menyerukan ketaatan dalam beberapa ayat alQur'an. Para Rasul diutus dengan membawa missi ketaatan kepada Allah, agar manusia keluar dari kegelapan hati, menuju pada kema'rifan yang suci. Dan agar manusia dapat bersenangsenang di dalam surga kenikmatan yang abadi yang disediakan bagi orang-orang yang bertaqwa. Tingginya kenikmatan surga belum pernah terlihat oleh penglihatan mata, tidak pula terdengar oleh telinga, dan bahkan belum terlintas pula dalam hati manusia.

Sesungguhnya manusia diciptakan tidak untuk kesia-siaan dan tidak pula hanya sekedar main-main belaka. Tetapi untuk diberikan balasan sesuai dengan amal ibadahnya, bagi mereka yang berbuat jahat akan dibalas dengan kejahatannya, dan bagi orang yang berbuat kebajikan akan dibalas dengan kebajikannya yang lebih baik. Allah, Dialah Tuhan Yang Maha Kaya, yang tidak butuh pada ketaatan manusia dan tidak pula membahayakanNya, kemaksiatan-kemaksiatan yang mereka lakukan, serta tidak mengurangi kesempurnaan-Nya sedikitpun.

Jika mereka menyombongkan diri, maka mereka (malaikat) yang di sisi Tuhanmu bertasbih kepada-Nya dimalam dan siang hari, sedang mereka tidak jemu-jemu. Barangsiapa yang beramal soleh maka ia akan berguna bagi dirinya sendiri, dan barangsiapa berbuat jahat maka ia akan membahayakan dirinya sendiri.

Bagaimana jika kita tidak mentaati Tuhan kita yang hakiki, yaitu Allah swt. Dia yang telah menciptakan dan membentuk serta meninggikan derajat kemuliaan pada kita. Tetapi begitu sering kita melakukan kesalahan-kesalahan yang tiada henti-hentinya. 
Sekalipun begitu Dia tidak mencegah nikmat-nikmat kepada kita, tetapi terus membentangkannya.

Bagi orang yang berakal, tentu dia mengerti siapa yang harus ditaati, Kepada siapa dia harus mengorientasikan segala aktivitasnya dalam kehidupannya, ketika berbuat dosa, maka Dia Tuhan yang akan menerima tobatnya, kepada sang Pencipta seseorang akan kembali, janganlah berputus asa akan rahmat-Nya. Hendaklah mensyukurinya, dengan begitu dia akan dicatat sebagai orang yang cinta kepada-Nya.

Hal itu kemudian ditegaskan lagi oleh Allah, dengan menerangkan bahwa kemenangan dan kebahagiaan hanyalah bisa diperoleh oleh perkara tersebut. Oleh karenanya, barangsiapa tidak melakukannya, maka ia bakal menemui berbagai macam penderitaan, kelak dihari kiamat yang sulit dilukiskan.

Bertaqwa kepada Allah adalah memelihara diri dari murka dan siksa Allah, dengan cara tidak melanggar agama dan syari'atNya. Ibnu jarir meriwayatkan dari Qatadah; Bahwa dia berkata mengenai penafsiran ayat ini : maksudnya, dekatkanlah dirimu pada Allah dengan mematuhi-Nya dan melakukan amal perbuatan yang membuat-Nya ridho."

Di sini dapat dikatakan, perbedaan yang radikal antara orang yang bertaqwa dan orang yang kufur ditunjukkan dalam kaitannya dengan dua hal yang sangat penting; pertama, apa yang mereka lakukan semasa hidup di dunia orang beriman hanya melakukan amal saleh belaka, sementara orang kafir menghabiskan usianya untuk mengejar kesenangan dunia semata. Kedua, apa yang mereka peroleh pada hari pembalasan, orang beriman akan mendapatkan pahala surga, sementara orang kafir akan masuk neraka. Dengan demikian diketahuilah, bahwa taqwa adalah suatu kedudukan tertinggi dalam surga. ${ }^{6}$

Seorang hamba yang telah diberi rezeqi oleh Allah dengan sepuluh perkara, berarti dia telah selamat dari neraka dan ancaman bahaya dan telah behasil derajat mutaqarribin dan muttaqin. Kesepuluh perkara tersebut adalah:

${ }^{6}$ Ahmad Musțofa al-Marāgi, Tafsir al-Marāgi, (Semarang: Toha Putra, 1993), h. 199-201. 
1. Ucapannya selalu jujur disertai dengan hati yang qonaah.

2. Selalu sabar dengan disertai rasa syukur yang terus menerus karena iman yang paling utama adalah sabar dan bersikap toleran.

3. Ridho dengan kefakiran disertai dengan zuhudyang nyata karena keridoan orang fakir itu akan mendapatkan keberuntungan atas pahala kefakirannya, jika tidak maka malah sebaliknya yaitu tidak akan mendapatkan keberuntungan. .

4. Banyak bertafakkur dengan keadaan perut yang lapar yaitu dengan bertafakkur dalam segala hal bukanlah bertafakkur atas Dzat Allah swt.

5. Senantiasa prihatin disertai dengan rasa takut kepada Allah karena yang dikatakan seseorang berilmu ialah apabila ia merasa takut kepada Allah swt.

6. Anti berpangku tangan dengan disertai ketawadhu'an karena jika kuat memiliki sifat tawadhu' akan terhindar dari sifat sombong.

7. Selalu bersikap lemah lembut disertai dengan kasih sayang karena kalu kita mempunyai sifat lemah lembut dan kasih sayang kita akan disegani dan dihargai orang lain.

8. Rasa cinta karena Allah disertai dengan sifat malu karena-Nya.

9. Ilmu yang bermanfaat dengan disertai amal yang langgeng karena Allah tidak akan memberikan manfaat pada ilmu kita jika kita tidak mengamalkannya.

10. Iman yang kekal dengan disertai akal sehat yang tetap adanya karena sebaik-baiknya karunia adalah akal dan seburukburuknya musibah adalah kebodohan. ${ }^{7}$

Bahwa seseorang dapat dikatakan bertaqwa harus memiliki lima hal diantarany: peratama; tidak suka bergaul, kecuali dengan orang yang dapat memperbaiki agamanya dan dapat membuatnya memelihara kemaluan dan lisannya. Kedua, jika mendapat musibah besar dalam urusan duniawi, ia menganggapnya sebagai hukuman karma. Ketiga, jika mendapatkan dalam musibah agama meskipun sedikit, ia bersedih. Keempat, tidak suka perutnya dipenuhi dengan makanan yang halal sekalipun, karena khawatir tercampur dengan

${ }^{7}$ Imam Nawawi, Nasihat-nasihat bagi untuk Para Hamba, (Bandung: Irsyad Baitus salam, 2005), h. 232-233. 
yang haram. Kelima, memandang orang lain bersih dari dosa, sementara memandang dirinya dengan penuh dosa. ${ }^{8}$

Hendaklah selalu melatih diri kita agar takwa kepada Allah. Takwa mengandung akan arti takut dan memelihara. Di dalamnya terkandung khauf dan Raja'. Khauf yang berarti takut, yaitu takut akan adzab-Nya. Takut azab-Nya. Dan mengharap akan rahmat-Nya (Raja'). Di samping pendirian taqwa yang demikian, hendaklah disusun wasilah, yaitu jalan-jalan dan cara supaya kian lama kian mendekati Tuhan. Yaitu dengan memperbanyak amal ibadah, berbuat kebajikan, bertambah dekatlah ke tempat yang dituju. Oleh sebab itu wasilah adalah adalah amal dan usaha sendiri. Bukan wasilah itu menggunakan perantara orang lain.

Islam juga menggambarkan cara untuk membentuk masyarakat insani yang utama dan ideal. Dan untuk itu, Islam menyiapkan semangat yang kondusif untuk pertumbuhan yang sehat dan pendidikan yang baik, sebagaimana Islam juga menyiapkan kesempatan-kesempatan yang memungkinkannya untuk sanggup memperlihatkan kemampuan-kemampuannya yang tersimpan.

Manusia muslim merupakan manusia ritus dan ibadah sebagai wujud ketaqwaannya kepada Allah swt, karena dia menyakdari dan mengetahui bahwa alam sekitar diciptakan untuknya, adapun dia maka tercipta untuk Allah semata, dengan demikian ia mengetahui tujuan hidupnya dan rahasia keberadaannya.

Beribadah kepada Allah semata tidak ada sekutu bagi-Nya, merupakan tujuan akhir dari segala tujuannya, maka untuknyalah ia tercipta dan karena ditundukkan untuknya apa yang ada di langit dan apa yang ada di bumi.

Kemudian Allah menciptakan manusia baik laki-laki dan perempuan, memiliki jabatan atau tidak, maka yang dilihat adalah ketakwaannya sebagai ukuran kepribadian manusia. Dalam QS. alHujarat (49): 13:

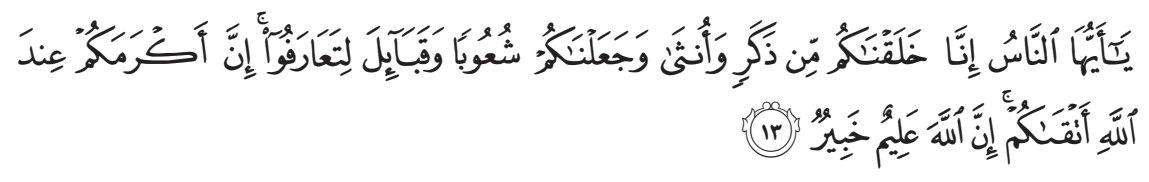

${ }^{8}$ Ibid, h. 130-131. 
"Hai manusia, sesungguhnya Kami menciptakan kamu dari seorang laki-laki dan seorang perempuan dan menjadikan kamu berbangsabangsa dan bersuku-suku supaya kamu saling kenal-mengenal. Sesungguhnya orang yang paling mulia diantara kamu disisi Allah ialah orang yang paling taqwa di antara kamu. Sesungguhnya Allah Maha Mengetahui lagi Maha Mengenal".

\section{Pengertian Makna Jihad}

Al-jihād, dari kata al-Juhdu, artinya kesukaran dan kepayahan. Sabilllāh, ialah jalan kebenaran, kebaikan dan keutamaan. Dan usaha apapun dalam rangka membela kebenaran adalah jihād fi sabilillāh.

Maksud ayat ini adalah, lawanlah nafsumu, dengan mencegahnya dari menuruti keinginan-keinginannya, dan membawanya untuk bersikap adil dan seimbang dalam keadaan apapun. Dan lawanlah musuh-musuh-Ku dan musuh-musuhmu. Biarlah dirimu menanggung susah dalam memerangi mereka dari melawan dakwah Islam. Lakukanlah semua itu dalam mengharap kebahagiaan, kemenangan dan kejayaan, baik di dunia maupun di akhirat, di samping kelanggengan dalam surga yang penuh kenikmatan.

Dan berjihadlah pada jalan-Nya, yakni kerahkanlah semua kemampuan kamu lahir dan batin untuk menegakkan nilai-nilai ajaran-Nya, termasuk berjihad melawan hawa nafsu kamu supaya kamu mendapatkan keberuntungan, yakni memperoleh apa yang kamu harapkan baik keberuntungan duniawi atau ukhrawi.

Jihad ialah "merupakan "ruhbaniyah" " pendetanya kaum muslimin. Maksudnya dengan jihad itu kaum muslimin telah meninggalkan kelezatan duniawiyah, menjauhkan diri dari para pelakunya, rela memikul kesulitan perjuangan dan penderitaan. ${ }^{9}$

Bermujahadah di jalan Allah (yaitu jalan-jalan kebajikan, hak dan keutamaan). Tahanlah dirimu dari segala yang diharamkan, tetaplah berjalan di jalan yang lurus, dan perangilah musuh-musuh Islam supaya agama, semuanya menjadi kepunyaan Allah. Kemudian berperanglah dan mempertahankan hak, kebenaran, kemerdekaan, kebajikan ummat, dan tanah air. Semua ini jihad di jalan Allah. ${ }^{10}$

${ }^{9}$ Wijaya Ibnu Hamzah dan Salim, Latar Belakang Historis Timbulnya Haditshadits Rasul 2 dan 3, (Jakarta: Kalam Mulia, 2004), h. 15.

${ }^{10}$ Zaitunah Artani Hasbi, Membetuk Pribadi Muslim, (Surabaya: Bina Ilmu, 


\section{Jihad Muslim Berdasarkan Ilmu Pendidikan Agamanya}

Seorang ahli ma'rifat menceritakan bahwa Hatim menyatakan sesunggguhnya jihad itu ada tiga macam, yaitu :

1. Jihad dalam menghadapi orang-orang kafir, ini merupakan jihad lahiriah, sebagaimana yang dijelaskan dalam firman Allah: "Mereka yang berjihad dijalan Allah."11

2. Jihad terhadap orang-orangyang batil, dengan jalan memberikan pengertian dan menyertainya dengan argumentasi (hujjah), sebagaimana yang dijelaskan dalam firman Allah. “dan bantahlah mereka dengan cara yang baik"(QS. Al-Nahl:125) ${ }^{12}$

3. Jihad melawan hawa nafsu, yang selalu memerintahkan untuk berbuat kejahatan. Sebagaimana yang dijelaskan dalam firman Allah.: "Dan orang-orang yang berjihad untuk (mencari keridhaan) Kami, benar- benar akan Kami tunjukkan kepada mereka jalan-jalan kami. dan Sesungguhnya Allah benar-benar beserta orang-orang yang berbuat baik.(QS. al-Ankabut : 69) ${ }^{13}$

Upaya jihad sebagaimana ajakan rasulullah untuk berjihad yaitu untuk melawan hawa nafsu. Nafsun adalah sesuatu yang selalu memerintahkan kita kepada keburukan dan kejahatan dan ini adalah lebih memusuhi kita daripada iblis. Kekuatan iblis mampu menguasai kita karena kita mengikuti hawa nafsu kita yang menyesatkan. Oleh sebab itu, jangnlah kita tertipu olehnya, melalui angan-angan kosong, tipu daya, bertindak lambat dan bermalas-malasan. Semua ajakan iblis adalah batil, semuanya adalah tipu daya yang menyesatkan. Jika kita senang dengan hawa nafsu lalu mengikutinya maka kita akan celaka. Jika kita lengah mengawasinya maka nerakalah yang kita akan rasakan kelak.

Oleh sebab itu, sudah seharusnya bagi orang yang berakal bertobat dari dosa-dosanya yang telah berlalu. Berpikir tentang hal-hal yang mendekatkan diri kepada Allah dan sabar dalam mengikuti hawa nafsu. Nafsu itu ibarat berhala, maka barangsiapa yang mengabdi pada nafsu, berarti ia telah mengabdi pada berhala.

1990), h. 174.

\footnotetext{
${ }^{11}$ Departemen Agama RI, Al-Qur'an ..., h. 75.

${ }^{12}$ Ibid, h. 403.

${ }^{13}$ Ibid., h. 628.
} 
Tetapi barangsiapa yang mengabdi kepada Allah dengan penuh keikhlasan, berarti dia telah mengalahkan hawa nafsunya.

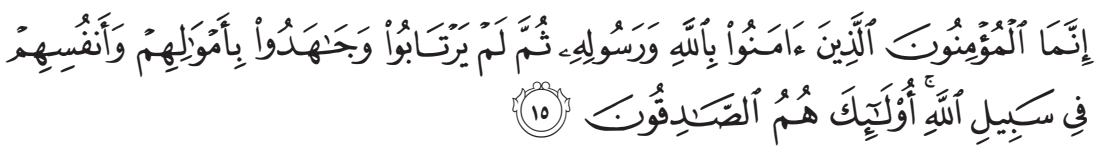

"Sesungguhnya orang-orang yang beriman itu hanyalah orang-orang yang percaya (beriman) kepada Allah dan Rasul-Nya, kemudian mereka tidak ragu-ragu dan mereka berjuang (berjihad) dengan harta dan jiwa mereka pada jalan Allah. mereka Itulah orang-orang yang benar. ${ }^{14}$

Bagi orang yang berakal, seharusnya mengendalikan hawa nafsunya dengan menahan lapar. Karena lapar merupakan pengendalian terhadap musuh Allah, sementara hal-hal yang menyuburkan setan adalah memperturutkan hawa nafsu, makan dan minum.

Sesunggguhnya manusia yang lebih dekat kepada Allah swt. Kelak di hari kiamat ialah orang-orang yang paling lama menahan lapar dan haus. Dan dosa yang paling besar dan yang dapat menghancurkan anak Adam adalah keinginan nafsu perut. Sebab keinginan nafsu perut Adam dan Siti Hawa diusir dari perkampungan yang abadi, yaitu surga pada perkampungan yang hina dan miskin, yaitu dunia.

Orang ahli hikmah mengatakan: "Barang siapa yang dikuasai hawa nafsunya, maka dia menjadi tertawan oleh kecintaan terhadap keinginan-keinginan dan terkungkung dalam kesalahankesalannya”. Dan keinginan hawa nafsunya akan menghalangi hatinya untuk menerima faedah. Barangsiapa menyirami anggotaanggota tubuhnya dengan memperturutkan hawa nafsunya, berarti ia menanam pohon penyesalan di dalam hatinya.

Allah swt menciptakan makhluk dalam tiga kategori. Dia menciptakan malaikat dan menyusun dalam dirinya akal tanpa dibekali hawa nafsu. Dia menciptakan binatang dan menyusun dalam dirinya tanpa akal namun dibekali hawa nafsu. Dan sementara Dia menciptakan manusia dan menyusun dalam dirinya akal dan dibekali hawa nafsu. Barangsiapa yang akalnya dapat mengalahkan

${ }^{14}$ Ibid., h. 845 
hawa nafsunya, maka dia mendapatkan tataran yang lebih baik daripada malaikat. ${ }^{15}$

\section{E. Jihad Muslim Berdasarkan Ilmu Pendidikan Sosial}

Lebih dari seorang Muslim merupakan insan jihad, maksudnya bahwa ia tidak berhenti pada kebaikan (kesalehan) dirinya, melainkan ia mencurahkan upayanya untuk memperbaiki (iṣlah) orang lain, dan mengajak orang lain untuk menuntut ilmu dan memperdalam ilmu dunia dan terlebih lagi ilmu akhirat kepada ajaran yang ditunjukkan Allah.

Seorang muslim memulai ilmu pendidikannya untuk pertama kalinya di lingkungannya sendiri, yaitu di kalangan keluarga, anak-anak dan keluarganya. Kemudian ilmu pendidikannya berlanjut di lingkungan masyarakat sekitar dengan menyerukan kepada kebaikan, memperingatkan dari kejahatan, memerintahkan kebajikan dan melarang kemungkaran. Oleh karena itu tidak boleh baginya bersikap seperti penonton atau apatis (tidak peduli) terhadap maraknya kemungkaran atau bertambahnya kebodohan karena kurangnya pendidikan melainkan ia harus tampil untuk merubah kemungkaran jika mampu dengan tangannya, jika tidak mampu maka dengan lisannya, jika tidak mampu juga maka dengan hatinya dan hal itu merupakan iman yang paling lemah.

Tidaklah dipahami dari "perubahan dengan hati" disini adalah merupakan sikap pasif melainkan ia adalah mendidihnya hati secara internal untuk menghadapi kebodohan yang semakin merata yang berdiri dibelakangnnya kekuatan (backing) yang zalim yang mendukung dan melindungi akan kemerosotan dunia pendidikan. Gelegak didih ini terwujud suatu hari secara nyata dalam amal positif yang memiliki urgensi dalam perubahan pendidikan.

Yang terlebih penting adalah kebodohan itu jangan sampai mengambil karakter legal secara de facto dengan lamanya didiamkan (ditolelir), karena inilah yang mengundang la'nat Allah terhadap masyarakat.

${ }^{15}$ Abdul Mujib, Kepribadian dalam Psikologi Islam, (Jakarta: PT. Raja Grafindo, 2006), h. 29-32. 
Walaupun orang-orang yang melakukan kebodohan atau melindunginya itu adalah dari oknum penguasa dan orang-orang terpenting. Sebaiknya seorang Muslim jangan merasa lemah dalam menghadapi mereka itu dengan perintah dan larangan secara hikmah dan nasehat secara baik dengan bersandarkan kepada kekuatan kebenaran yang ada pada dirinya dan pada keyakinan bahwa Allah swt. Bersamanya, tidak seorangpun berkuasa pada dirinya untuk menguranginya dan ajalnya berada di sisi Allah telah ditentukan, tidak mundur sesaatpun maupun maju. Inilah jihad Fisabilillah melalui ilmu pendidikan yang dianggap yang mulia yang berada pada puncaknya.

Seorang Muslimpun tidak boleh berhenti pada jihad internal (dakhili) dengan hanya berdakwah dan amar ma'ruf nahi munkar, melainkan dia harus berjihad dengan lisannya, jiwanya, hartanya agar kalimat Allah sampai kepada seluruh umat Islam. ${ }^{16}$

\section{F. Pengertian Kepribadian Muslim}

Kepribadian Muslim berarti kepribadian orang Islam. Kata "Islām" seakar dengan kata al-salām, al-salm dan al-silm yang berarti menyerahkan diri, kepasrahan, ketundukan, kepatuhan; kata "al-silm" dan "al-salm" yang berarti damai dan aman; dan kata "alsalm," "al-salām" dan "al-salāmah" yang berarti bersih dan selamat dari cacat, baik lahir maupun batin. Orang yang berislam adalah orang yang menyerah, tunduk, patuh, dan melakukan perilaku yang baik, agar hidupnya bersih dari lahir maupun batin yang pada gilirannya akan mendapatkan keselamatan dan kedamaian di dunia dan di akhirat.

Penyerahan diri sepenuh hati pada Zat yang muthlak membawa kedamaian yang sejati, ibarat seorang pasien yang diliputi kepanikan, ketakutan dan kehampaan hidup, kemudian ia menyerahkan persoalannya pada psikiater maka ia akan mendapatkan kedamaian dan keselamatan. Perilaku individu yang menyebabkan kekacauan dan kekhawatiran sesungguhnya merupakan antitesis dari tujuan hakiki ajaran Islam, sekalipun ia orang Muslim. ${ }^{17}$

\footnotetext{
${ }^{16}$ Yusuf Qorḍawi, Bagaimana..., h. 243-247

${ }^{17} \mathrm{Ibid}$, h. 249-250.
} 
Kepribadian Muslim yang hakiki ialah sesuatu yang didambadambakan oleh orang-orang yang bertaqwa. Mereka mencurahkan sebagian besar usahanya untuk meraih hal itu dengan cara berserah diri (bertawakkal) kepada Allah swt mengharap rahmatNya, khawatir akan siksa-Nya, malu terhadapnya, cinta dan rindu kepada-Nya, bersyukur akan nikmat-nikmat-Nya, sabar menghadapi cobaan-cobaan-Nya, menerima takdir-Nya tetap taat kepada-Nya, memohon pertolongan dari-Nya, serta bertobat kepada-Nya. Inilah yang oleh kalangan tasawuf biasa disebut "maqām".

Beberapa nilai Rabbaniah dan maqām ruhiyah di atas, tak pelak, merupakan indikasi-indikasi keimanan dan sekaligus buahnya. Maka barangsiapa yang sudah sempurna keimanannya, niscaya nilai-nilai tersebut akan tertanam dan tertancap kuat dalam dirinya.

Di antara tujuan al-Qur'an ialah mengajak untuk mensucikan jiwa manusia. Tidak ada keberuntungan di dunia dan di akhirat kecuali dengan pensucian ini. Jiwa dengan fitrahnya siap menerima kefasikan yang mengotorinya, sebagaimana kesiapannya untuk menerimaa ketaqwaan yang mensucikannya. Maka manusia dengan akal dan kehendak-Nya harus memilih salah satu di antara dua jalan ini, yaitu jalan pensucian tahukah jalan pengotoran. Tidak dapat diragukan bahwa jika dia memilih jalan pensucian. ${ }^{18}$

1. Kepribadian Muslim Syahadatain

Syahadatain berasal dari kata "syahida" yang berarti bersaksi, menghadiri, melihat, mengetahui, dan bersumpah. Istilah syahadatain kemudian dinisbatkan pada satu momen di mana individu mengucapkan dua kalimat syahadat dengan ucapan :"Aku bersaksi tiada tuhan selain Allah, dan aku bersaksi bahwasanya Muhammad adalah utusan Allah".

Kalimat syahadat terdiri dari atas dua kesaksian. Keyakinan pertama berkaitan dengan keyakinan tiada Tuhan selain Allah, sedang kesaksian kedua adalah mengenai Muhammad adalah utusan Allah. Kedua saksi ini tidak boleh diabaikan salah satunya, sebab jika diabaikan salah satunya maka menjadikan ketidak bermaknaan salah satunya. Bacaan tiada Tuhaan selain Allah memiliki arti tiada

${ }^{18}$ Ibid, h. 255-263. 
tuhan (ilah) selain Allah yang ada (maujud) kecuali Allah. Syahadah pertama merupakan aktualisasi dari tauhid ulūhiyyah (ketuhanan). Sedangkan syahadat Rasul memiliki arti bahwa Nabi Muhammad saw. Merupakan utusan Allah penutup dan akhir.

Kepribadian syahadatain adalah merupakan kepribadian individu yang didapat setelah mengucapkan dua kalimat syahadat, memahami hakikat dari ucapannya serta menyadari akan segala konsekwensi persaksiannya tersebut. Kepribadian syahadatain meliputi domain kognitif dengan pengucapan dua kalimat syahadat secara verbal; domain afektif dengan kesadaran hati yang tulus dan domain psikomotorik dengan melakukan segala perbuatan sebagai konsekuensi dari persaksiannya itu.

2. Kepribadian Muslim Muṣalli

Kepribadian muṣalli adalah kepribadian individu yang didapat setelah melaksanakan shalat dengan baik, konsisten, tertib dan khusyu', sehingga mendapatkan hikmah dari apa yang dikerjakan. Pengertian ini didasarkan atas asumsi bahwa orang yang tekun shalat memiliki kepribadian lebih saleh ketimbang orang yang tidak megerjakannaya sebab ia mendapatkan hikmah dari perbuatannya.

3. Kepribadian Muslim Șaim

Kepribadian șaim adalah kepribadian individu yang didapat setelah melaksanakan puasa dengan penuh keimanan dan ketaqwaan, sehingga ia dapat mengendalikan diri dengan baik. Pengertian ini didasarkan atas asumsi bahwa orang yang mampu diri dari yang membatalkan puasa memiliki kepribadian lebih kokoh, tahan uji, dan stabil ketimbang orang yang tidak mengerjakannya, sebab ia mendapat kan hikmah dari perbuatannya.

4. Kepribadian Muslim Muzakki.

Muzakki adalah orang yang telah mengeluarkan zakat. Zakat secara etimologi berarti berkembang (al-namw) dan bertambah (al-ziyādah), baik secara kuantitas maupun kualitas (keberkahan). Orang yang membayar zakat, hartanya cenderung bertambah bukan semakin berkurang.

Menurut istilah, zakat adalah mengeluarkan sebagian harta kepada orang yang berhak menerimannya ketika mencapai batasnya 
(nișab). Dan kepribadian muzakki adalah kepribadian individu yang didapat setelah membayar zakat dengan penuh keikhlasan, sehingga ia mendapatkan hikmah atas apa yang dilakukanya.

Pengertian ini didasarkan atas asumsi bahwa orang yang membayar zakat memiliki kepandaian bergaul, dermawan, terbuka, berani berkurban, memiliki kepekaan social dan mudah menyesuaikan diri, sekalipun pada orang yang beda statusnya.

5. Kepribadian Muslim Haji.

Haji adalah orang yang telah melaksanakan haji. Haji menurut etimologi berarti menyengaja (al-qașd) pada sesuatu yang diagungkan. Orang yang melaksanakan haji berarti hatinya selalu menuju pada Zat yang Maha Tinggi. Menurut istilah, haji adalah menyengaja pergi ke Baitullah (ka'bah) untuk melaksanakan syarat (Islam, baligh, berakal, merdeka, dan mampu), rukun (niat ihram dari miqāt, wuquf di arafah, țawaf ifaḍah, sa'i, cukur dan tertib) dan bermalam di Muzdalifah, menginap di Mina, melontar jumroh dan țawaf wada') pada bulan yang ditentukan (Syawal, Dzu al-Qa'dah dan Dzu al-Hijjah).

Kepribadian haji adalah kepribadian individu yang didapat setelah melaksanakan hajiyang semata-mata dilakukan karena Allah Swt Sehingga ia mendapatkan hikmah dari apa yang dilakukan. ${ }^{19}$

\section{G. Karakteristik Kepribadian Muslim}

Seseorang yang beruntung seharusnya merasa puas dengan apa yang diberikan oleh Allah padanya, dan memutus beberapa harapan serta berpaling dari apa yang di tangan orang lain. Tidak menggebu-gebu dan besar kecintaannya untuk bekerja hanya mencari harta semata, tanpa mengenal waktu dan tidak pula halal dan haram. Bekerja mengais rizki untuk mencukupi yang tidak bias dilepaskan begitu saja, yaitu kebutuhan akan makanan, pakaian dan tempat tinggal, hari demi hari atau bulan demi bulan bahkan tahun demi tahun. Tidak menyibukkan hatinya untuk memenuhi kebutuha melebihi batas maksimal. Apabila merindukan dan mendambakan yang lebih banyak atau memperpanjang angannya, maka dia tidak memiliki sifat qona'ah dan jiwanya terkotori oleh sifat

${ }^{19}$ Ibid., h. 130-131 
rakus. Kerakusan itu akan mengotori dan menyeret dia mempunyai prilaku jahat dan berakhlak tercela, melakukan kemungkaran dan merobek kehormatan dan kemuliaan.

Sebagai Muslim yang ingin menuju kejayaan, kemenangan serta keberuntungan harus menempuh jalan sebagai berikut: Pertama Taqwa kepada Allah Kedua Mengatur jalan supaya dapat cepat sampai kepada Allah degan beribadah, beramal soleh dan doa. Ketiga Berjihad bersungguh-sungguh atau bekerja keras mengatasi segala penghambat perintang yang akan menghambatnya sampai kepada keridoaan Allah.

Inti Kepribadian Muslim yang berilmu: Pertama Menyerahkan diri kepada Allah. Kedua Kebebasan dan Kemuliaan Manusia. Ketiga Membebaskan Pribadi Muslim dari Faktor-Faktor Ketakutan. ${ }^{20}$

\section{H. Kewajiban Seorang Muslim}

Manusia muslim merupakan manusia ritus dan ibadah, karena dia menyadari dan mengetahui bahwa alam sekitar diciptakan untuknya, adapun dia maka tercipta untuk Allah semata, dengan demikian ia mengetahui tujuan hidupnya dan rahasia keberadaannya. Beribadah kepada Allah semata tidak ada sekutu bagi-Nya, merupakan tujuan akhir dari segala tujuannya, maka untuknyalah ia tercipta dan karena ditundukkan untuknya apa yang ada di langit dan apa yang ada di bumi.

Manusia tidaklah diciptakan kecuali untuk melayani Robbnya dan Penciptanya yaitu untuk beribadah kepada-Nya dengan menyembah-Nya semata tanpa menyekutukan-Nya dengan seseorang atau sesuatu apapun dari makhluk-Nya di bumi ataupun di langit. Ibadah untuk pertama kalinaya termanifestasikan dalam mendirikan ibadah-ibadah ritual (Syiar) yang besar yang diwajibkan Islam dan dijadikannya termasuk rukun Islam yang besar berupa shalat, puasa, zakat, haji kemudian apa yang menyempurnakannya dari dzikir, doa, tilawah al-Qur'an, tahlil dan takbir. ${ }^{21}$

${ }^{20}$ Imam Nawawi, Nasehat..., h. 130-131.

${ }^{21}$ Yusuf Qardawi, Pengantar kajian Islam., terj. Setiawan Budi Utomo, (Jakarta: Pustaka al-Kautsar, 2003), h. 236-237. 


\section{Penutup}

Di antara hak Sang Khalik, pemberi rizki dan nikmat ialah disyukuri dan tidak dikufuri, diingat dan tidak dilalaikan, ditaati dan tidak didurhakai, yang semua tidak akan terwujud kecuali dengan melaksanakan ibadah secara murni. Ibadah merupakan hak Allah semata.

Tidak ada agama seperti Islam, yang menyuruh menyembah Allah semata dan menganjurkannya, mengaitkan orang Muslim dengan Rabb-nya dengan ikatan yang kuat, lewat berbagai macam ibadah, seperti shalat lima waktu yang sifatnya harian, ibadah mingguan seperti shalat jum'at, ibadah tahunan seperti puasa Ramadhan, ibadah sepanjang tahun seperti haji.

Di antara ibadah-ibadah itu ada yang praktis seperti shalat, adapula yang sifatnya harus tidak meninggalkannya, seperti puasa, ada yang bersifat fisik seperti shalat dan puasa, ada yang bersifat material seperti zakat, ada yang bersifat memadukan antara keduanya seperti haji dan jihad.

Di antara ibadah itu ada yang ada yang hukumnya wajib 'ain seperti empat macam pokok, yang disusul dengan kewajibankewajiban sosial yang diperintahkan al-Qur'an, seperti berbuat bajik kepada orang tua, kerabat, anak-anak yatim, orang-orang miskin, tetangga dekat, kemudian tetangga yang lebih jauh lagi dan ibnu sabil.

Di antara ibadah yang hukumnya fardhu kifayah, yang jika sudah dilaksanakan sebagian orang, maka tidak ada lagi dosa bagi semua umat, seperti shalat janazah, shalat Id, jaminan untuk masyarakat, mempersiapkan kekuatan material dan militer yang diperlukan untuk membela umat, mempersiapkan para mujahidin untuk meninggikan agama, mendidik para ahli dan pakar dalam segala bidang kehidupan dunia.

Di antara ibadah yang nafilah, seperti zikir kepada Allah, berdoa, beristighfar dan membaca al-Qur'an. Semua ibadah ini menjadikan orang Muslim bertaqwa kepada Allah seperti yang sudah disebutkan di atas, "Sembahlah Rabb kalian yang telah menciptakan kalian dan orang-orang yang sebelum kalian,Agar kalian bertaqwa." Makna taqwa adalah menjauhi. Dengan kata lain, menjauhi 
kemurkaan Allah dan menjauhi apa yang dibenci-Nya. Apa yang dibenci-Nya adalah hal-hal yang dilarang dan meninggalkan apa yang diperintah. Karena itu kata taqwa ini merupakan ungkapan mengikuti perintah dan meninggalkan larangan. Asasnya ialah takut kepada Allah. Hal ini termasuk amal hati. Karena itu ibadah ini dinisbatkan kepada taqwa dalam hati.

Ajakan al-Qur'an pada taqwa menggunakan berbagai macam cara, dari perintah secara langsung, menjelaskan beberapa pengaruhnya, pujian terhadap orang yang bertaqwa , memaparkan kebaikan dan keutamaan mereka, peringatan terhadap orang yang meninggalkan dan berpaling kepada-Nya, sehingga jelas perbedaan orang yang bertaqwa dengan orang-orang yang yang berpaling yang berbuat kekejian, atau orang-orang yang baik dan bertaqwa dengan orang-orang yang berbuat dosa dan pelanggaran. [ ]

\section{Daftar Pustaka}

Amrullah, Abdul Malik Abdul Karim, Tafsir al-Azhar, Jakarta: PT. Pustaka Panjimas, 2000.

Al-Ghazali, Menyingkap Rahasia Qolbu, Surabaya: Amelia, 2004.

Ibnu Hamzah, Wijaya dan Salim, Latar Belakang Historis Timbulnya Hadits-hadits Rasul 2 dan 3, Jakarta: Kalam Mulia, 2004.

Hasbi, Zaitunah Artani, Membetuk Pribadi Muslim, Surabaya: Bina Ilmu, 1990.

al-Hasyimi, M. Ali, Muslim Ideal, Bandung: Irsyad Baitus salam, 2004.

Izutsu, Etika Beragama dalam Islam, Jakarta: Pustaka Firdaus, 1993.

Jalaludin, Psikologi Agama, Jakarta: PT. Raja Grafindo, 2005.

Madjid, Nurcholis, Islam Doktrin dan Peradaban, Jakarta: Paramadina, 2000.

al-Maragi, Ahmad Mustofa, Tafsir al-Maragi, Semarang: Toha Putra, 1993.

Mujib, Abdul, Kepribadian dalam Psikologi Islam, Jakarta: PT. Raja Grafindo, 2006. 
Nawawi, Imam, Nasihat-nasihat bagi untuk Para Hamba, Bandung: Irsyad Baitus salam, 2005.

Rahardjo, Ensiklopedi al-Qur'an, Jakarta: Paramadina, 1996.

al-Ṣafti, Ali Muhammad Khalil, Membangun Komitmen Seorang Muslim, Jakarta: Gema Insani, 2003.

Sa'aduddin, Imam Abdul Mukmin, Meneladani Akhlak Nabi, Bandung: PT. Rosadakarya, 2006. 